\title{
mRNA expression profiles of heat shock proteins of wild and salinity-tolerant swimming crabs, Portunus trituberculatus, subjected to low salinity stress
}

\author{
X.N. Bao, C.K. Mu, C. Zhang, Y.F. Wang, W.W. Song, R.H. Li and \\ C.L. Wang \\ School of Marine Science of Ningbo University, Ningbo, China \\ Corresponding author: C.L. Wang \\ E-mail: wangchunlin@nbu.edu.cn
}

Genet. Mol. Res. 13 (3): 6837-6847 (2014)

Received June 25, 2013

Accepted November 12, 2013

Published August 29, 2014

DOI http://dx.doi.org/10.4238/2014.August.29.5

\begin{abstract}
Challenged by the low salinity, 4 parts per thousand (4 ppt), for $72 \mathrm{~h}$, the survivals of swimming crabs (Portunus trituberculatus) were collected as the screened group (SG, tolerant to low salinity). Aiming at identifying the mechanism of low salinity tolerance, quantitative real-time PCR was employed to investigate the expression profiles of 4 HSP genes (HSP60, HSP70, HSP90-1, HSP902 ) in the hepatopancreas of wild (WG) and screened (SG) groups of $P$. trituberculatus exposed to low salinity (4 ppt). The results showed that 3 of the candidate genes (HSP60, HSP 70, HSP 90-1) exhibited similarly downregulated expression profiles in the first $3 \mathrm{~h}(\mathrm{P}<0.05)$, which became upregulated from $3 \mathrm{~h}$ to $72 \mathrm{~h}$ after being subjected to low salinity conditions. In contrast, the expression profile of the HSP90-2 gene was upregulated during the first $6 \mathrm{~h}$ for the WG, and during the first $12 \mathrm{~h}$ for the SG, after which it became downregulated. HSP90-1 and HSP90-2 were highly expressed at $12 \mathrm{~h}$ after low salinity challenge in the $\mathrm{SG}$, but not the WG. The response of these 2 genes to salinity stress indicates
\end{abstract}


their suitability as biomarkers to differentiate SG from WG crabs. The results indicate that HSP genes are involved in the adaptation of crabs to low salinity exposure, and that different HSPs have diverse functions in response to low salinity stress in P. trituberculatus. In addition, HSP expression in SG indicates that this group is more tolerant to low salinity conditions compared to WG.

Key words: Portunus trituberculatus; Low salinity stress; qRT-PCR; HSP

\section{INTRODUCTION}

Heat shock proteins (HSPs) are a family of highly conserved proteins involved in the stress response formed during the process of biological evolution (Feder and Hofmann, 1999). HSPs are classified into 5 families based on their molecular weights; including HSP100, HSP90, HSP70, HSP60, and small HSPs (Georgopoulos and Welch, 1993; Moseley, 1997). These proteins have been reported to be present in all organisms from bacteria to mammals, and play critical roles in protein folding, assembly, intracellular localization, and the regulation of gene expression (Morimoto, 1998; Terasawa et al., 2005). Abnormal environment factors (such as high temperature, heavy metals, high or low salinity) that could potentially damage cells stimulated the production of HSPs (Deane et al., 2002; Spees et al., 2002a). To date, several studies have reported the expression modes of HSPs under salinity stress. For example, when Atlantic salmon (Salmo salar) are transferred to high-salinity sea water, HSP90 levels significantly increased(Pan et al., 2000). In addition, the expression of HSP70 and HSP90 in the abdominal muscle of the lobster Homarus americanus exhibits major changes under both low and high salinities (Spees et al., 2002b).

The swimming crab, P. trituberculatus, is widely distributed in the coastal waters of Japan, Korea, and China (Dai et al., 1986), and is a commercially important fishery and aquaculture species in China (Sun, 1984). As a euryhaline crab species, $P$. trituberculatus tolerates a wide range of ambient salinities, from $10 \mathrm{ppt}$ to $38 \mathrm{ppt}$, with optimal salinities of $20 \mathrm{ppt}$ to $35 \mathrm{ppt}(\mathrm{Ji}, 2005)$. However, some individuals exhibit high flexibility to extremely low salinity. Such individuals have been screened for use in the field of genetics and breeding, due to their great practical value in production practices. In our previous research, a large number of crabs $(2.97 \pm 0.44 \mathrm{~g})$ were placed in a salinity of $4 \mathrm{ppt}$ for about $72 \mathrm{~h}$, with the surviving individuals being collected for culture under normal conditions. Subsequently, the surviving individuals were designated as the screened group (SG). Then, SG and wild group (WG) individuals were separately bred under the same environmental conditions for the further experiments.

The entire life history of the swimming crab is influenced by external environmental salinity. Although the saline adaptability of swimming crabs involves a series of reactions at the individual, protein, and molecular level, the osmotic regulation mechanism at the molecular level might underlie this species' adaption to saline conditions. The molecular characterization of HSP60, HSP70, and HSP90 from P. trituberculatus have been previously reported (Zhang et al., 2009; Cui et al., 2010; Xu and Qin, 2012). In this paper, the expression levels of HSP60, HSP70, HSP90-1, and HSP90-2 in the hepatopancreas of WG and SG swimming crabs, $P$. trituberculatus, during $72 \mathrm{~h}$ exposure to low salinity (4 ppt) were detected, with the purpose of identifying the mechanism of low salinity tolerance. 


\section{MATERIAL AND METHODS}

\section{Animals and sample treatment}

WG and SG swimming crabs (P. trituberculatus) were collected from a commercial farm in Xiangshan, China. Individuals were fed with frozen fish once daily from $5 \mathrm{pm}$ to $6 \mathrm{pm}$. For the salinity challenge, the normal salinity of seawater was $30 \mathrm{ppt}$, and a normal temperature was maintained at $\left(27.8 \pm 1^{\circ} \mathrm{C}\right)$. Then, crabs, averaging $(64.1 \pm 6.4 \mathrm{~g})$ of WG and $(66.5 \pm 4.3 \mathrm{~g})$ of SG in body weight, were exposed to 4 ppt salinity stress, and sampled at $0,3,6,12,24,48$, and $72 \mathrm{~h}$ after challenge. The hepatopancreas of each crab was sampled and stored at $-80^{\circ} \mathrm{C}$ until analysis.

\section{RNA purification and first-strand synthesis of cDNA}

Total RNA was extracted by the RNAiso Plus (Takara, Tokyo, Japan) following manufacturer protocols. The integrity of RNA was detected on $1.0 \%$ agarose gel, and the RNA was stored at $-80^{\circ} \mathrm{C}$ before use. The first-strand of cDNA was obtained by a RevertAid ${ }^{\mathrm{TM}}$ First Strand cDNA Synthesis Kit (Thermo, MD, USA) in a $20-\mu \mathrm{L}$ volume containing total $5 \mu \mathrm{g}$ RNA and $5 \mu \mathrm{M}$ oligo (dT) primer. The mixture was incubated at $42^{\circ} \mathrm{C}$ for $1 \mathrm{~h}$, terminated by heating at $70^{\circ} \mathrm{C}$ for $5 \mathrm{~min}$, and subsequently stored at $-80^{\circ} \mathrm{C}$.

\section{Quantification of mRNA expression levels}

qRT-PCR was performed by SYBR Premix Ex Taq ${ }^{\text {TM }}$ (Takara, Tokyo, Japan). Amplification was carried out on a 96-well plate in $20-\mu \mathrm{L}$ reaction volume containing $10 \mu \mathrm{L}$ 2xSYBR Premix Taq ${ }^{\mathrm{TM}}$ (Takara, Tokyo, Japan), $0.3 \mu \mathrm{L}$ PCR forward primer (10 pM), 0.3 $\mu \mathrm{L}$ reverse primer $(10 \mathrm{pM}), 1.5 \mu \mathrm{L}$ cDNA template (samples diluted 5 times), and $7.9 \mu \mathrm{L}$ $\mathrm{ddH}_{2} \mathrm{O}$. The thermal profile for real-time PCR was $95^{\circ} \mathrm{C}$ for $2 \mathrm{~min}$, followed by 40 cycles at $95^{\circ} \mathrm{C}$ for $5 \mathrm{~s}$ and $60^{\circ} \mathrm{C}$ for $15 \mathrm{~s}$. Four pairs of specific primers (HSP60F/HSP60R, HSP70F/ HSP70R, HSP90-1F/HSP90-1R, and HSP90-2F/HSP90-2R) were used to detect the transcripts of HSP60, HSP70, HSP90-1, and HSP90-2 respectively. $\beta$-actin was used as the internal control. All primers used in this study are shown in Table 1. A melting curve analysis $\left(60\right.$ to $95^{\circ} \mathrm{C}$, with increments of $0.5^{\circ} \mathrm{C}$ per second) was added after the amplification to confirm that only one product was amplified and detected. $\mathrm{ddH}_{2} \mathrm{O}$ was used instead of cDNA template as PCR negative control.

\section{Table 1. Informations of primers used in this study.}

\begin{tabular}{lll}
\hline Primers & Sequence $\left(5^{\prime}\right.$ to $\left.3^{\prime}\right)$ & Sequence information \\
\hline HSP60F & AGGAGCGAATGGCACGACT & Q-RT HSP60 primer \\
HSP60R & ATCCAGGGCAGGCAAGCAG & Q-RT HSP60 primer \\
HSP70F & CCGTATCCCTAAGACCCAGAAA & Q-RT HSP70 primer \\
HSP70R & CAGCCTCAGACTTATCACCACAAA & Q-RT HSP70 primer \\
HSP90-1F & CTATCCCATCAGGCTCCTTGTT & Q-RT HSP90-1 primer \\
HSP90-1R & CACCTACATCCTCAATCTTTGGCTT & Q-RT HSP90-1 primer \\
HSP90-2F & TCTCTTCGCCTTCGCCTCTCA & Q-RT HSP90-2 primer \\
HSP90-2R & AAGCGTTCGTGGATGGTGCGT & Q-RT HSP90-2 primer \\
$\beta$-actin-F & TCACACACTGTCCCCATCTACG & Q-RT actin primer \\
$\beta$-actin-R & ACCACGCTCGGTCAGGATTTTC & Q-RT actin primer \\
\hline
\end{tabular}




\section{Data analysis}

All experiments were performed in triplicate. Gene expression level was determined by the $2^{-\Delta \Delta \mathrm{Ct}}$ method. All data are reported as means $\pm \mathrm{SD}$ (standard deviation) in terms of their relative mRNA expression. The results were analyzed by one-way analysis of variance (oneway ANOVA), followed by the Duncan multiple range tests using the SPSS software 19.0. P values less than 0.05 were considered to be statistically significant.

\section{RESULTS}

\section{Expression profiles of HSP60 after low salinity challenge}

The HSP60 expression level in the 2 groups of swimming crabs followed a similar pattern (Figure 1). For the WG (Figure 1A), HSP60 expression significantly decreased at 3 $\mathrm{h}(\mathrm{P}<0.05)$. From 3 to $48 \mathrm{~h}$, HSP expression alternately increased and decreased, but with no significant difference $(\mathrm{P}>0.05)$, then it sharply increased at $72 \mathrm{~h}(\mathrm{P}>0.05)$. For the $\mathrm{SG}$ (Figure 1B), HSP60 expression was significantly reduced during the first $3 \mathrm{~h}(\mathrm{P}<0.05)$, but gradually rose from 3 to $48 \mathrm{~h}$, and then dramatically rose to the highest level at $72 \mathrm{~h}(\mathrm{P}<0.05)$.

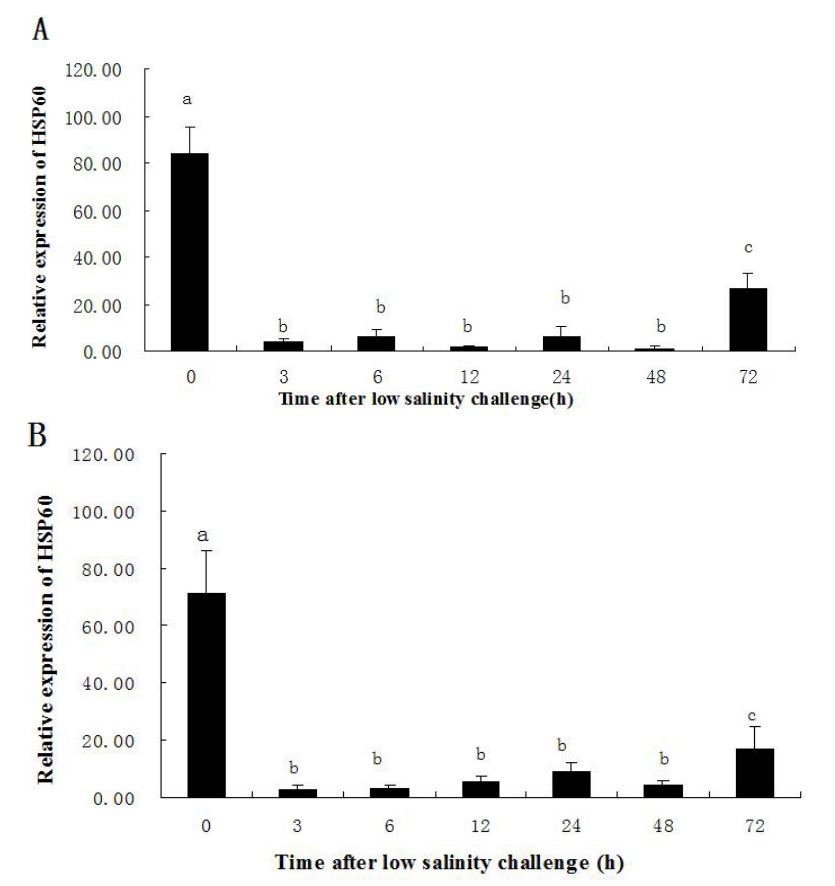

Figure 1. Relative expression level of HSP60 in hepatopancreases after low salinity (4 ppt) stress of wild swimming crab. A. Screened swimming crab; B. measured by SYBR Green RT-PCR. The $\beta$-actin gene is used as an internal control to calibrate the cDNA template for all the samples in each determination. Each bar represents the mean value from four determinations with standard error. The hepatopancreases were collected from four individual crabs at $0,3,6,12,24,48$, and $72 \mathrm{~h}$. Different lowercase letters indicate statistically significant differences $(\mathrm{P}<$ 0.05 ) in relative expression of each gene among different sampling time points. 


\section{Expression profiles of HSP70 after low salinity challenge}

As shown in Figure 2, the HSP70 transcripts from both groups under low salinity (4 ppt) stress had a curvilinear trend as time progressed. Compared to the control (untreated $0 \mathrm{~h}$ ), the expression of HSP70 in both groups initially declined in the first $3 \mathrm{~h}(\mathrm{P}<0.05)$ and then increased (Figure 2). In contrast, at $48 \mathrm{~h}$ post-stress, the HSP70 transcripts of SG (Figure 2B) almost recovered to the original level, whereas that of WG (Figure 2A) was maintained at a low level until $72 \mathrm{~h}$.
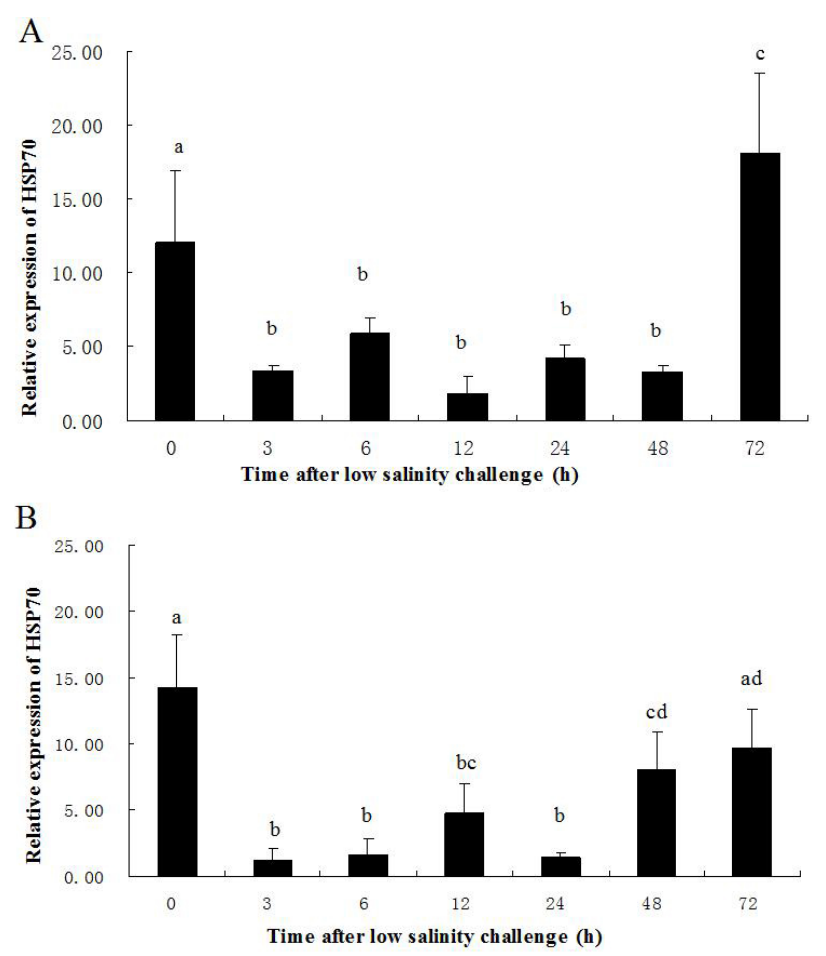

Figure 2. $H S P 70$ transcript temporal expression relative to $\beta$-actin in hepatopancrease of wild swimming crab. A. Screened swimming crab; B. after low salinity (4 ppt) stimulation was analyzed by RT-PCT. Each bar represents the mean value from four determinations with standard error. The hepatopancreases were collected from four individual crabs at $0,3,6,12,24,48$, and $72 \mathrm{~h}$. Different lowercase letters indicate statistically significant differences $(\mathrm{P}<$ 0.05 ) in relative expression of each gene among different sampling time points.

\section{Expression profiles of HSP90-1 after low salinity challenge}

The expression pattern of HSP90-1 in the 2 groups is shown in Figure 3. At $3 \mathrm{~h}$ after stress, the expression level in both groups rapidly declined $(\mathrm{P}<0.05)$. However, the expression of WG (Figure 3A) was maintained at an extremely low level, without significant change $(\mathrm{P}>0.05)$ from 6 to $48 \mathrm{~h}$, but markedly increased at $72 \mathrm{~h}(\mathrm{P}<0.05)$. In comparison, that of $\mathrm{SG}$ (Figure 3B) rose to a higher level at 12 and $24 \mathrm{~h}(\mathrm{P}<0.05)$, then decreased $(\mathrm{P}<0.05)$ at $48 \mathrm{~h}$, and remained relatively stable from 48 to $72 \mathrm{~h}(\mathrm{P}>0.05)$. 


\section{A}

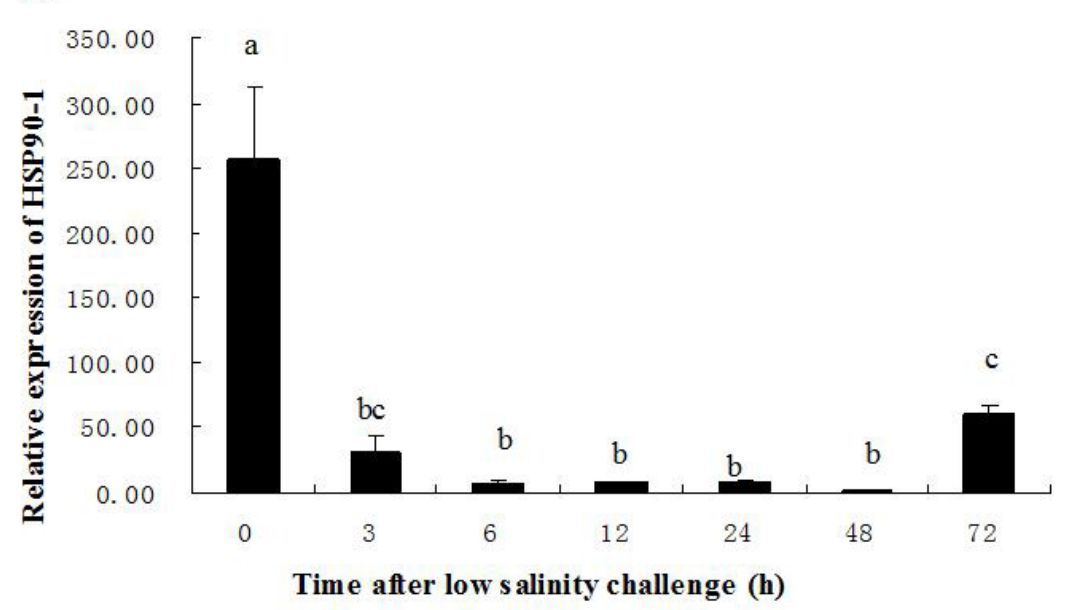

A

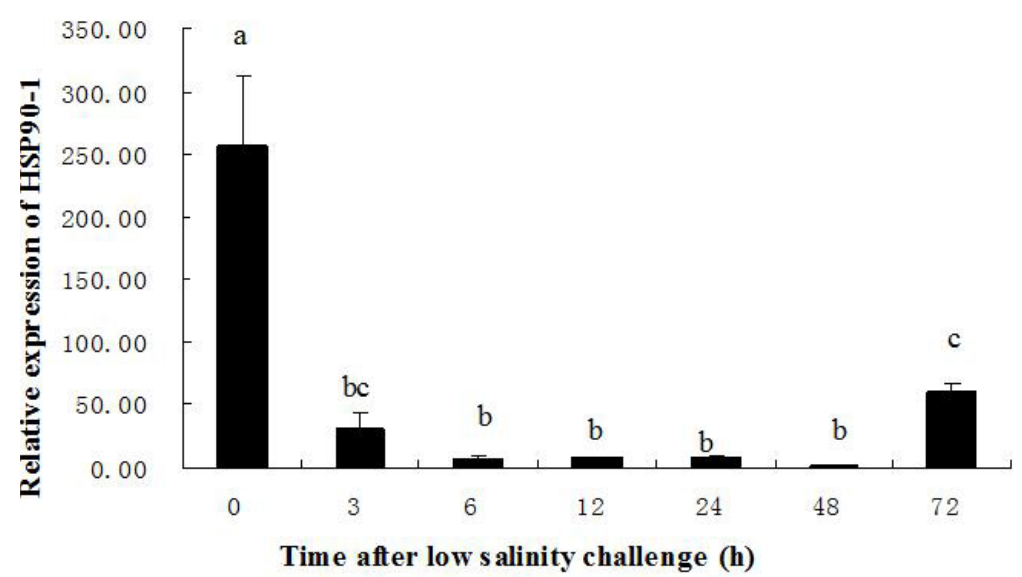

Figure 3. Temporal expression of HSP90-1 relative to $\beta$-actin of wild swimming crab. A. Screened crab; B. analyzed by real-time PCR in Portunus trituberculatus hepatopancreases after low salinity challenge. Each bar represents the mean value from four determinations with standard error. The hepatopancreases were collected from four individual crab at $0,3,6,12,24,48$, and $72 \mathrm{~h}$. Different lowercase letters indicate statistically significant differences $(\mathrm{P}<0.05)$ in relative expression of each gene among different sampling time points.

\section{Expression profiles of HSP90-2 after low salinity challenge}

HSP90-2 exhibited the opposite trend to HSP60, HSP70, and HSP90-1 (Figure 4). For the WG (Figure 4A), HSP90-2 expression was significantly upregulated from 0 to $6 \mathrm{~h}$ (P $<0.05$ ), and reached a maximum at $6 \mathrm{~h}$. Afterwards, the expression level gradually decreased, with a further decline by $72 \mathrm{~h}$, but remained higher compared the initial level. For the SG (Figure 4B), HSP90-2 expression gradually rose from $0 \mathrm{~h}$ to $6 \mathrm{~h}(\mathrm{P}>0.05)$, and reached a dramatic maximum at $12 \mathrm{~h}(\mathrm{P}<0.05)$. Then, the expression level dropped significantly from $12 \mathrm{~h}$ to 24 
$\mathrm{h}$, and remained relatively stable from 24 to $72 \mathrm{~h}(\mathrm{P}>0.05)$; however, the expression level at $72 \mathrm{~h}$ was twice as high compared to the original level.

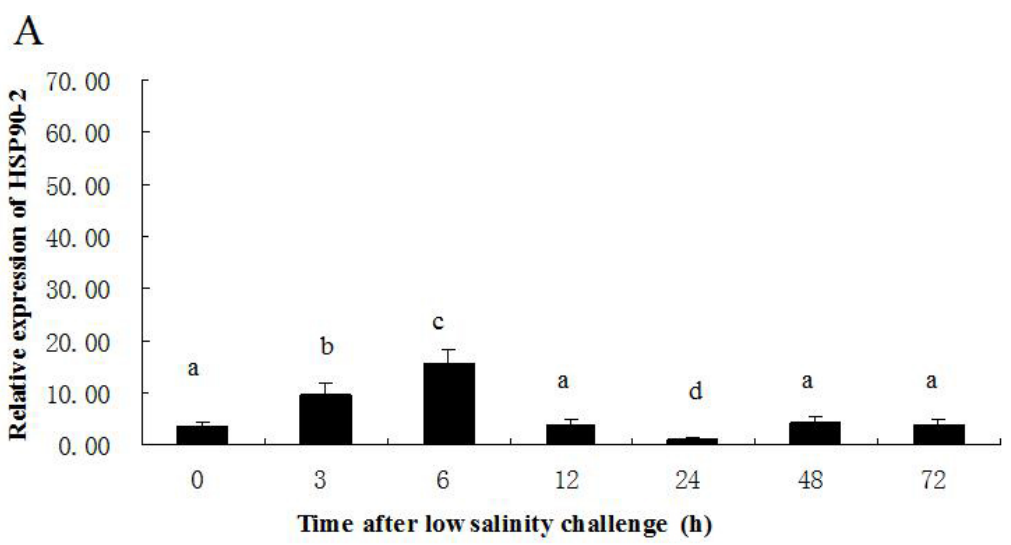

B

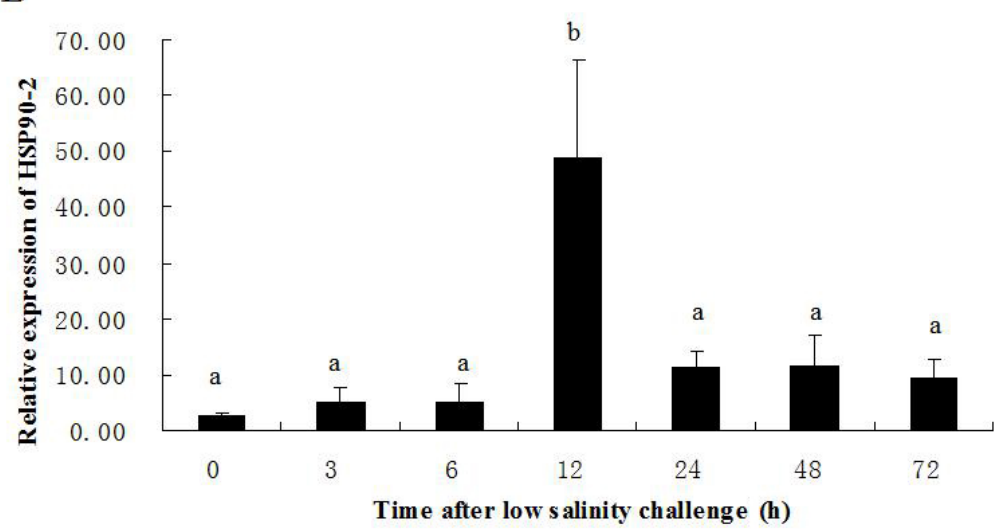

Figure 4. Relative mRNA levels of HSP90-2 genes in hepatopancrease of wild swimming crab. A. Screened swimming crab; B. after exposure to low salinity (4 ppt) was evaluated by RT-PCR. Each bar represents the mean value from four determinations with standard error. The hepatopancreases were collected from four individual crabs at $0,3,6,12,24,48$, and $72 \mathrm{~h}$. Different lowercase letters indicate statistically significant differences $(\mathrm{P}<$ 0.05 ) in relative expression of each gene among different sampling time points.

\section{DISCUSSION}

The HSP genes are considered to be critical elements during the salinity acclimation process (Xu and Liu, 2011). In crustaceans, the hepatopancreas has been identified as the vital tissue for immune defense (Söderhäll and Cerenius, 1998). The involvement of HSP genes in both high and low salinity responses has been demonstrated in many aquatic animals. It has been demonstrated that the expression level of HSP70 gradually increases after low salinity exposure in the gill of Mytilus galloprovincialis (Hamer et al., 2004), but decreases in the gill of Chamelea gallina (Monari et al., 2011). The overexpression of HSP70 has also been re- 
ported in the hemocytes of Scylla paramamosain after high salinity stress (Yang et al., 2013). The expression of HSP90 was induced when Crassostrea hongkongensis (Fu et al., 2011) and Crassostrea gigas (Jo et al., 2008) were subject to salinity stress. In the lobster, Homarus americanus, the expression of HSP70 and HSP90 in the abdominal muscle increased after salinity stress, whereas $H S P 90$ levels remained unchanged in the hepatopancreas (Spees et al., 2002b). These studies demonstrate that HSP genes play critical roles in the ability of animals to cope with abnormal salinity challenge.

The HSP60 expression pattern in the 2 groups of swimming crabs differs to that in the gill of P. trituberculatus (Xu and Qin, 2012) and the pleopod of the shrimp, Litopenaeus vannamei (Huang et al., 2011) when subject to 10-ppt salinity challenges. This difference might arise because HSP60 exhibits tissue-specific expression patterns or because the salinity in our study was much lower compared to that used in previous studies. For the WG (Figure 1A), HSP expression significantly decreased at $3 \mathrm{~h}$. Then, from 6 to $48 \mathrm{~h}$, HSP expression alternately increased and decreased with no significant difference $(\mathrm{P}>0.05)$, and reached the lowest point at $48 \mathrm{~h}$. However, at $72 \mathrm{~h}, \mathrm{HSP}$ mRNA expression was significantly enhanced. For the SG (Figure 1B), the HSP60 transcript level was sharply downregulated during the first $3 \mathrm{~h}(\mathrm{P}<0.05)$, but gradually increased from 3 to $72 \mathrm{~h}$, which might strengthen the organisms immunity to protect it from further damage (Ranford and Henderson, 2002; Tsan and Gao, 2004). In addition, it contributes to the folding of nascent proteins, post-translation. As a molecular chaperone, an important activity of HSP60 is the mediation of the native folding of proteins (Ellis and van der Vies, 1991). It seems that the expression level was more unstable for the WG than the SG.

HSP70 indicates the presence of physiological stress (Dahlhoff et al., 2001), and exerts its specific protective function in all organisms (de la Vega et al., 2006). The transcriptional expression of HSP70 showed a time-dependent response in the hepatopancreas after crabs were challenged with low salinity. In general, the expression level in both the SG and WG first decreased and then increased. A similar tendency was obtained in a previous study on Eriocheir sinensis (Sun et al., 2012); however, our results differed to a study on the lobster Homarus americanus (Spees et al., 2002b). This difference might have been influenced by the energy depletion of osmoregulation and the very low salinity (4 ppt) in our study. HSPs require ATP to function. Impaired stress protein function associated with reduced ATP levels has been previously established (Feige et al., 1996; Roberts et al., 1997). It has been postulated that energy depletion caused by increased osmoregulation under low salinity conditions might lead to reduced levels of HSP70 proteins in the swimming crab, and has also been observed in all tissues of P. amurensis (Werner and Hinton, 2000) and in the gill of Chamelea gallina (Monari et al., 2011). In the current study, as time progressed, HSP70 expression increased to protect organisms from further damage (de la Vega et al., 2006). For the SG (Figure 2B), expression levels remained low during the first $24 \mathrm{~h}$. Then, HSP70 expression increased at $48 \mathrm{~h}$, and continued to increase $(\mathrm{P}>0.05)$ until $72 \mathrm{~h}$, almost reaching the initial level. However, for the WG (Figure 2A), the expression level remained low until $48 \mathrm{~h}$, and then sharply rose at $72 \mathrm{~h}(\mathrm{P}<0.05)$. This result indicates that the SG had adapted to the low salinity when the stress time reached $48 \mathrm{~h}$. In addition, this result also indicated that $\mathrm{SG}$ required less time to adapt to the low salinity environment compared to WG.

As a molecular chaperone, HSP90 plays an important role in folding new peptides, along with refolding and stabilizing denatured proteins, under stressful conditions (Sreedhar et al., 2004). In vertebrates, 2 subtypes of HSP90 have been identified; namely, the stressinducible HSP90 $\alpha$ and the constitutively expressed HSP90 $\beta$ (Heikkila, 2010). In P. trituber- 
culatus, 2 complete HSP90s (HSP90-1, HSP90-2) genes that exhibit tissue-specificity have been reported (Zhang et al., 2009). In the present study, the expression level of HSP90-1 was downregulated and then upregulated, but remained lower compared to the initial level. It is possible that the 4 ppt was so low that it fell beyond the salinity range that induces the production of HSP90-1; thus, disrupting protein synthesis in organisms (Huhtala et al., 2005). A similar expression pattern has been reported in the gill of Crassostrea hongkongensis under low salinity stress (Fu et al., 2011). In the current study, the high expression of HSP90-1 at 12 and $24 \mathrm{~h}$ was apparent in the SG (Figure 3B), but not the WG (Figure 3A). The increase in expression level from $3 \mathrm{~h}$ to $24 \mathrm{~h}$ might contribute to the refolding of denatured proteins to protect organisms from environmental stress (Sanders, 1993; Grzesiuk and Mikulski, 2006). In comparison, the expression level decreased between 24 and $72 \mathrm{~h}$, which might be because long-time exposures to low salinity are harmful to organisms.

However, the opposite trend appeared in the expression profile of HSP90-2 in swimming crabs, which was consistent with a previous report (Zhang et al., 2009). The expression level of HSP90-2 in the 2 groups first increased and then progressively decreased, which was similar to that observed in the gill of $C$. hongkongesi (Fu et al., 2011) and the branchial lamellae of $S$. salar (Pan et al., 2000) under high salinity stress. For the WG (Figure 4A), there was a dramatic increase during the first $6 \mathrm{~h}(\mathrm{P}<0.05)$ after challenge, and reached a maximum at $6 \mathrm{~h}$. Then, the expression level dropped to almost the initial level at $12 \mathrm{~h}$, and even sharply decreased to the lowest level at $24 \mathrm{~h}(\mathrm{P}<0.05)$. Afterwards, the expression level increased again from 24 to $72 \mathrm{~h}$, and recovered to the initial level at $72 \mathrm{~h}$. For the SG (Figure 4B), there was no obvious change during the first $6 \mathrm{~h}$ after challenge; however, a significant increase was observed at $12 \mathrm{~h}$, and then the expression decreased again. Although the expression level from 24 to $72 \mathrm{~h}$ remained steady $(\mathrm{P}>0.05)$, and higher compared to the original, there was no major difference compared to the original level $(\mathrm{P}>0.05)$. The high expression level of HSP90-2 during the first $6 \mathrm{~h}$ in the WG and at $12 \mathrm{~h}$ in the $\mathrm{SG}$ helps to protect organisms against environmental stress. Subsequently, the expression level was downregulated; hence, it is possible that the overexpression was insufficient to counteract the damage to proteins following a long period of low salinity stress, and then inhibited the metabolic process (Meng et al., 2011). We found that between 6 and $12 \mathrm{~h}$ the SG was post-challenged to increase the expression level to protect the organism (Grzesiuk and Mikulski, 2006). The SG might have some advantageous mechanisms enabling them to adapt better to low salinity conditions compared to the WG. We also inferred that HSP90-1 and HSP90-2 played quite different roles in the resistance to low salinity.

In conclusion, we compared the expression profiles of HSP60, HSP70, HSP90-1, and HSP90-2 in the hepatopancreas of wild and salinity-tolerant swimming crabs subject to low salinity challenge. The HSP60 and HSP70 expression level of SG was obviously more stable and required less time to adapt the low salinity conditions compared to the WG. The high expression of HSP90-1 and HSP90-2 at $12 \mathrm{~h}$ indicated that the SG had a strong ability to adapt to a low salinity environment. This study provides a new insight about the relationship between HSPs and salinity acclimation, which might be beneficial for developing breeds that are resistant to low salinity.

\section{ACKNOWLEDGMENTS}

The authors thank all the laboratory members for continuous discussion and technical ad- 
vice. Research supported by the National High Technology Research and Development Program of China (\# 2012AA10A409), the National Natural Science Foundation of China (\#41106123, \#41376150), Zhejiang Major Special Program of Breeding (\#2012C12907-3 and \#2012C129079), the Scientific Research Fund of Zhejiang Provincial Education Department (\#Z201121258), the Public Interest Program of Zhejiang Province (\#2013C31032), the Ningbo Innovative Program of Agriculture (\#2012C92010), National Sparking Plan Project (\#2013GA701002, \#2013GA701002), the major program of Ningbo (\#2013C11017), Program for Science and Technology Innovative Research Team of Ningbo (\#2011B81003), and K. C. Wong Magana Fund in Ningbo University.

\section{REFERENCES}

Cui Z, Liu Y, Luan W, Li Q, et al. (2010). Molecular cloning and characterization of a heat shock protein 70 gene in swimming crab (Portunus trituberculatus). Fish Shellfish Immunol. 28: 56-64.

Dahlhoff EP, Buckley BA and Menge BA (2001). Physiology of the rocky intertidal predator Nucella ostrina along an environmental stress gradient. Ecology 82: 2816-2829.

Dai AY, Yang SL and Song YZ (1986). Marine Crabs in China Sea. Marine Publishing Company, Beijing.

de la Vega E, Hall MR, Degnan BM and Wilson KJ (2006). Short-term hyperthermic treatment of Penaeus monodon increases expression of heat shock protein 70 (HSP70) and reduces replication of gill associated virus (GAV). Aquaculture 253: 82-90.

Deane EE, Kelly SP, Luk JC and Woo NY (2002). Chronic salinity adaptation modulates hepatic heat shock protein and insulin-like growth factor I expression in black seabream. Mar. Biotechnol. (NY) 4: 193-205.

Ellis RJ and van der Vies SM (1991). Molecular chaperones. Annu. Rev. Biochem. 60: 321-347.

Feder ME and Hofmann GE (1999). Heat-shock proteins, molecular chaperones, and the stress response: evolutionary and ecological physiology. Annu. Rev. Physiol. 61: 243-282.

Feige U, Morimoto RI, Yahara I and Polla BS (1996). Stress-inducible Cellular Responses. Birkhäuser Verlag, Basel.

Fu D, Chen J, Zhang Y and Yu Z (2011). Cloning and expression of a heat shock protein (HSP) 90 gene in the haemocytes of Crassostrea hongkongensis under osmotic stress and bacterial challenge. Fish Shellfish Immunol. 31: 118-125.

Georgopoulos C and Welch WJ (1993). Role of the major heat shock proteins as molecular chaperones. Annu. Rev. Cell Biol. 9: 601-634.

Grzesiuk M and Mikulski A (2006). The effect of salinity on freshwater crustaceans. Pol. J. Ecol. 54: 669-674.

Hamer B, Hamer DP, Müller WE and Batel R (2004). Stress-70 proteins in marine mussel Mytilus galloprovincialis as biomarkers of environmental pollution: a field study. Environ. Int. 30: 873-882.

Heikkila JJ (2010). Heat shock protein gene expression and function in amphibian model systems. Comp. Biochem. Physiol. A Mol. Integr. Physiol. 156: 19-33.

Huang WJ, Leu JH, Tsau MT, Chen JC, et al. (2011). Differential expression of LvHSP60 in shrimp in response to environmental stress. Fish Shellfish Immunol. 30: 576-582.

Huhtala A, Linko P and Mutharasan R (2005). Protein response of insect cells to bioreactor environmental stresses. $J$. Biotechnol. 118: 278-289.

Ji DS (2005). Techniques of pond-farming of swimming crab, Portunus trituberculatus. Spec. Econ. Anim. Plant 8: 12-13.

Jo PG, An KW, Peak MS and Choi CY (2008). mRNA expression of HSP90 and SOD, and physiological responses to thermal and osmotic stress in the Pacific oyster, Crassostrea gigas. Molluscan Res. 28: 158-164.

Meng XL, Dong YW, Dong SL, Yu SS, et al. (2011). Mortality of the sea cucumber, Apostichopus japonicus Selenka, exposed to acute salinity decrease and related physiological responses: Osmoregulation and heat shock protein expression. Aquaculture 316: 88-92.

Monari M, Foschi J, Rosmini R, Marin MG, et al. (2011). Heat shock protein 70 response to physical and chemical stress in Chamelea gallina. J. Exp. Mar. Biol. Ecol. 397: 71-78.

Morimoto RI (1998). Regulation of the heat shock transcriptional response: cross talk between a family of heat shock factors, molecular chaperones, and negative regulators. Genes Dev. 12: 3788-3796.

Moseley PL (1997). Heat shock proteins and heat adaptation of the whole organism. J. Appl. Physiol. (1985) 83: 1413-1417.

Pan F, Zarate JM, Tremblay GC and Bradley TM (2000). Cloning and characterization of salmon hsp90 cDNA: upregulation by thermal and hyperosmotic stress. J. Exp. Zool. 287: 199-212.

Ranford JC and Henderson B (2002). Chaperonins in disease: mechanisms, models, and treatments. Mol. Pathol. 55: 
209-213.

Roberts DA, Hofmann GE and Somero GN (1997). Heat-shock protein expression in Mytilus californianus: acclimatization (seasonal and tidal-height comparisons) and acclimation effects. Biol. Bull. 192: 309-320.

Sanders BM (1993). Stress proteins in aquatic organisms: an environmental perspective. Crit. Rev. Toxicol. 23: 49-75.

Söderhäll K and Cerenius L (1998). Role of the prophenoloxidase-activating system in invertebrate immunity. Curr. Opin. Immunol. 10: 23-28.

Spees JL, Chang SA, Snyder MJ and Chang ES (2002a). Thermal acclimation and stress in the American lobster, Homarus americanus: equivalent temperature shifts elicit unique gene expression patterns for molecular chaperones and polyubiquitin. Cell Stress Chaperones 7: 97-106.

Spees JL, Chang SA, Snyder MJ and Chang ES (2002b). Osmotic induction of stress-responsive gene expression in the lobster Homarus americanus. Biol. Bull. 203: 331-337.

Sreedhar AS, Kalmár E, Csermely P and Shen YF (2004). Hsp90 isoforms: functions, expression and clinical importance. FEBS Lett. 562: 11-15.

Sun YM (1984). Larval development of the swimming crab, Portunus trituberculatus. J. Fish. China 8: 219-226.

Sun M, Jiang K, Zhang F, Zhang D, et al. (2012). Effects of various salinities on $\mathrm{Na}^{+}-\mathrm{K}^{+}$-ATPase, Hsp 70 and $H_{s p} 90$ expression profiles in juvenile mitten crabs, Eriocheir sinensis. Genet. Mol. Res. 11: 978-986.

Terasawa K, Minami M and Minami Y (2005). Constantly updated knowledge of Hsp90. J. Biochem. 137: 443-447.

Tsan MF and Gao B (2004). Heat shock protein and innate immunity. Cell Mol. Immunol. 1: 274-279.

Werner I and Hinton DE (2000). Spatial profiles of hsp70 proteins in Asian clam (Potamocorbula amurensis) in northern San Francisco Bay may be linked to natural rather than anthropogenic stressors. Mar. Environ. Res. 50: 379-384.

Xu Q and Liu Y (2011). Gene expression profiles of the swimming crab Portunus trituberculatus exposed to salinity stress. Mar. Biol. 158: 2161-2172.

Xu Q and Qin Y (2012). Molecular cloning of heat shock protein 60 (PtHSP60) from Portunus trituberculatus and its expression response to salinity stress. Cell Stress Chaperones 17: 589-601.

Yang Y, Ye H, Huang H, Li S, et al. (2013). Expression of Hsp70 in the mud crab, Scylla paramamosain in response to bacterial, osmotic, and thermal stress. Cell Stress Chaperones 18: 475-482.

Zhang XY, Zhang MZ, Zheng CJ, Liu J, et al. (2009). Identification of two hsp90 genes from the marine crab, Portunus trituberculatus and their specific expression profiles under different environmental conditions. Comp. Biochem. Physiol. C Toxicol. Pharmacol. 150: 465-473. 